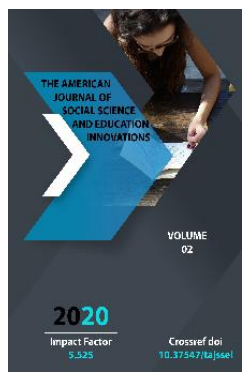

\title{
The Tasks Of Tourism In Aesthetic Education: The Harmony Of Historicity And Modernity
}

\author{
Bakhtiyor Hoshimovich Mirzarahimov \\ Researcher, Fergana State University, Fergana, Uzbekistan
}

Journal Website:

http://usajournalshub.c

om/index,php/tajssei

Copyright: Original

content from this work

may be used under the

terms of the creative

commons attributes

4.0 licence.

\section{ABSTRACT}

The article analyzes such conclusions as the rational use of national values in the improvement of environmental ecology through tourism, the development of the current sphere of enlightenment with folk mythology, oral and written creativity. The tasks of tourism activity in aesthetic education is mentioned about the function of providing information (informative), regulating (regulative), entertaining, educational, communicative activities, making educated, enlightening. Also, the fact that tourism is a complex system that includes the emotional and mental abilities of a person, his imagination about life, not only natural necessity, but also the real thing that is created on the basis of the laws of beauty-together with phenomena, forms of behavior, the harmonization of historicity and modernity are dialectically analyzed.

\section{KEYWORDS}

Aesthetic education, tourism, pilgrimage, education, gnoseological practice, Islam, aesthetic exteriors.

\section{INTRODUCTION}

Aesthetic education of a person is a complex and multifaceted process, a process associated with the thinking, worldview of a person. In these processes, aesthetics can manifest itself from a practical point of view through the culture of tourism. A person, as a result of his journey to nature, can enjoy beauty, splendor, but also master it delicately. 
Tourism improves the ability of people not only to actively master the samples of creativity built by mankind, but also to understand and evaluate their aesthetic essence. Tourism serves people to develop a culture of aesthetic attitude to the social processes of nature and society, to awaken a sense of glory to our historical spiritual heritage, to form national defiance, national pride. Therefore, tourism is an important means of aesthetic education with the creation of material and spiritual beauties.

One of the factors of aesthetic education in tourism is environmental and ecoesthetic activity. Today, one of the attitudes of man towards nature and society is the emergence of tourism activity, which requires a revision of the activities of modern aesthetic education. One of these is eco-friendly problems. The first and important step towards achieving the ecological-moral ideal is the internal transformation of our morals and views.

Studies on the fact that tourism is a means of modern eco-aesthetic education are revived a little later, a number of works are being carried out in the field of man, personality, society and nature. In tourism activities, they put forward hypotheses such as the elimination of environmental problems, the achievement of tolerance formation through the formation of an aesthetic attitude of a person to nature. There are also conclusions such as the rational use of national values in the improvement of environmental ecology through tourism, the development of the current sphere of enlightenment with folk mythology, oral and written creativity. Tourism can perform an important theoreticalphysiological function in the process of forming an aesthetic attitude of a person to nature, the discovery of natural beauty determines the ideological direction of a person in his creativity and understands the need for active participation in the development, transformation and preservation of the eco-aesthetic education reflecting the deep needs of a person through tourism.[1]

In the field of tourism research, the visit emphasizes the role of tourism in the spiritual and aesthetic education of a person. Pilgrimage is a person's journey through various holy places, which is carried out together with the performance of religious duties. It presupposes that a person visits religious or secular holy places, based on worship, moving away from his permanent address. The pilgrim carries out the pilgrimage by going to the holy place and things and worshiping, honoring them. This form of tourism serves as the basis of pilgrimage tourism. Because, in the process of visiting, pilgrims go on a trip with the purpose of visiting sacred places. Pilgrimage helps a person achieve spiritual and physical perfection through aesthetic sensuality. In the process of the visit, people get acquainted with the sacred place and things, receive spiritual nourishment from them, witness various events, such processes contribute to the worldview of the pilgrims and to their perfection.

\section{MATERIALS AND METHODS}

The purpose of this study is to base on the fact that tourism is a tool of aesthetic education in the globalisation era in the formation of the aesthetic ideal of the individual, aesthetic extention in the individual, the actions that satisfy it develop in the mood of the consumer. The main methodology in this article is a comparative analysis, an analysis of historicity, analogy and 
logic. In the evolution of tourism sources, it is mainly mentioned about the etiquette of travel and its aesthetic essence, its content.

In particular, Husayn Voiz Koshifiy expresses these thoughts."...If they ask for what purpose they will travel, answer, say that the sufis will travel for three things: to visit the great saints, either to see the mathematics of passion, or to see the land of the generous who have entered the way of the sect. The benefits of the trip are many, firstly, it is useful for the quality of the body, because the air changes and the organs become tender, so movement removes the rotubate of the body, improves blood circulation. Secondly, the reward of visiting the grave of the great people of dear-saints is very much in vain. Thirdly, indolence eliminates laziness because if he lives in a status of sluggishness and illness, the nutrients of the body, water will not go away. Fourthly, it removes bitterness, grief and melancholy, no matter how sad the next person goes on a journey, the excitement will be resolved, the journey from gold will take a lifetime. In the fifth, you can learn a lot in the journey that will increase your knowledge by walking on the journey" [2].

Muhammad Abu Hamid Ghazzali, an outstanding philosopher who has proved that science and religion are not enemies to each other, but friends, expresses the following thoughts about the aesthetic educational features of the journey in his work "Kimyoi saodat". "Travel to get knowledge is obligatory. It is obligatory and circumcised while studying so knowledge. If a person sets out to learn knowledge from his house, he will be walking until he comes to his house to get knowledge. Talibul-ilm on the path, Angels spread their wings. Sufyun Sabri rahmatullohi said:"if a person travels from Damascus to Yemen and hears a word from sharia science, his travel will not be a waste." And travel for this knowledge will make prosperous the next world. The second way is to travel to correct one's morals and get rid of the evil, hately qualities. Such a trip is important, when a person is at home he does what he wants. He loves himself and all his qualities. When he is on a journey of time, his evil temperament becomes known to him, and from the grief of the journey he finds out his weakness, inferiority and misfortune.[3] The trip will cause you to form better quality and correct morals. Bishr Hofi rahmatullohi alayh said: "O my loved ones, travel, so that you will be clean. It breaks the taste while the water stays in one place for a long time."[4]

As can be seen from the thoughts of our scientists who lived in the Middle Ages, the rules of the law, which developed aesthetics, have in common for modern tourism. Tourism as an aesthetic education it is not difficult to know how to carry even today. It can be seen that in social development, tourism is a means of aesthetic education that satisfies the spiritual need in a cultural context that becomes a value.

The Philosopher P.Sorokin analyzed the social trends of society in the middle of the $X X$ century and noted that in the history of Western civilization the priority of the emotional world, culture of the individual, the system of axiological consciousness continues. Describing an aesthetically perfect society, he wrote: "he analyzes tourism mainly as a satisfaction of well-being, health, physical perfection, aesthetic extention. [5] In our opinion, the axiological nature of society includes the basic printotypes of tourism culture. It can satisfy the physical, cultural and 
political needs of the individual, positively affect his physical, aesthetic, spiritual world. And this is a form of determining the social status of a tourist, along with the observance of values of a certain tourism activity, as well as a means of aesthetic education.

\section{RESULT AND DISCUSSION}

The peculiarities and principles of aesthetic education of tourism in a certain sense also determine its main functions. We will try to consider these tasks.

Liberating is the main task of tourism. Travel cleanses the soul of man - it serves as a purifying spiritual process.

The process of travel requires a person to give up bad morality and try to be kind, so that he can remove all worldly harmonies from the human soul. As a result, it rises from the state of impurity to the state of purity. Cleanse the human soul, express the original state it needs in everyday life: pure as water, transparent as a crystal, creating a smooth soul in a mirror.

Visit-means to go somewhere. A visit means, in essence, to go to holy places, to the graves of saints, to cemeteries, to perform certain rituals.[6]

According to Islamic beliefs, asking for help from the spirit of the saint being visited is considered a forbid and is considered a grave sin. Instead of asking for salvation from the pilgrims, it is appropriate to pray for their rights, to devote the reward formed from charity to their soul. When visiting the churchyard of dear saints, they are usually asked and prayed for the deceased. The role of tourism in bringing young people different views of the ancestors of the holy shrines as a sacred value to the future generation is also incomparable. In particular, the visit of the younger generation to the holy shrines, in turn, serves as an area of communication between the youth and the older generation, and the holy shrines, along with receiving valuable information about their history, traditions and values, visiting manners, rituals, have a special significance in their spiritual outlook.

Making educated is also one of the main tasks of tourism. The role of tourism in bringing different views of the ancestors of the stepmother to the future generation as a sacred value in youth is incomparable. In particular, the visit of the younger generation to the holy shrines, in turn, serves as an area of communication between the youth and the older generation, and the holy shrines play a major role in their spiritual outlook along with receiving valuable information about their history, traditions and values, visiting manners, rituals.The well-known English sociologist J.Urri interpreted the tourism industry as a social program, a modern way of knowing the world.[7] From this point of view, tourism relies on the increase of information in cognition through its aesthetic-emotional impact on man. Tourism in this sense can be called a gnoseological practice.[8] Tourism is an activity consisting of conscious, creative communication of man with nature and society. Its practical relevance with the object is an indicator of knowing exactly the essence of the material thing, overcoming its resistance. In tourism, man, in addition to studying the laws and properties of nature, opens up new opportunities and sets new goals, in accordance with which he assimilates new things that do not exist in nature through aesthetic sentiment.[9]

Important features of tourism as a genoseological phenomenon are: 1) travel 
according to purpose (values); 2) aesthetic emotional characteristics; 3) world, assimilation of things and cognitiveness. Taking into account the general unity of such signs as purposefulness, aesthetic - feeling character and cognitiveness makes tourism a gnoseological phenomenon. [10]

The function of upbringing. As an educator, tourism influences human emotions, evokes aesthetic senses and through this form the ability to distinguish evil from good. The educational function of tourism is that as a result of travel, a person receives knowledge and experience, in addition to tempering, overcoming difficulties, misses and appreciates his country, he becomes respectful of the customs of another nation. Tourism plays a great role in the growth of the worldview of a person, achieving spiritual maturity.[11]

Communicative activity is a specific function of tourism. Tourism "carries" the perception in a certain space and time, "introduces" the reality that is new to us, takes the modern man to another era, to another place of historical events, to another mint, to another region". Any culture that is created acts as a link (communicative) between people, groups, strata, peoples, nationalities. This function of tourism can affect a person both positively and negatively. For example, alien cultural formations that lie in the nature and spirituality, moral and aesthetic views of the peoples of the East negatively affect our people. But common sense, rights, artistic thinking, norms of faith, which are valued by all-human beings, have a positive impact on people and help to form a perfect person.

Leisure is a social function of tourism. Separately, it should be said that tourism can be associated with aesthetic exteriors. Therefore, the function of entertainment can be called its natural duty. For man, tourism is necessary "to have a taste", to enjoy for a while and get pleasure. Tourism is the knowledge of a person's social reality. A person, knowing the surrounding world, realizes that he is the true creator of selfmaterial wealth, his role and position in society. Along with the task of providing the ideological and artistic integrity of tourism, it also includes preserving it from ancestor to generation.

The duty of tourism to provide information (informative). As a result of mastering and understanding of the material world and the social environment that surrounds a person, he acquires a certain level of knowledge, experience, skills and abilities. They will have the need to deliver them to other people, groups or strata, generations coming after them. In the early periods of human life, that is, before the discovery of writing, people delivered their knowledge, experience, skills through samples of folk oral creativity, and then through writing. Tourism develops oral thinking and contemplative processes in a person, which is exactly why tourism can be called a modern means of aesthetic education. The regulatory (regulative) task of tourism. Relations of people with respect to nature, society and other people are regulated by state organizations, the policies they conduct, the rights that strengthen and disseminate it, as well as ideology, morality, art, sociohumanitarian sciences and religion, which are considered the main elements of the structure of society. Various rituals and customs, which are considered a social phenomenon are also manifested as the regulatory function of tourism. Moral, aesthetic, religious, political and legal norms are formed as a result of the 
orderly relations of people with respect to the environment.

\section{CONCLUSION}

Tourism as a modern means of aesthetic education can be concluded as follows. Tourism is a process aimed at satisfying the aesthetic needs of a person, allowing him to see places, learn and get aesthetic pleasure. Tourism as an integral part of spiritual education provides harmonious development of a person in aesthetic processes. The aesthetic aspect is one of the foundations of modern tourism culture, the emotional perception print forms the basis of some types of tourism: gastronomic, ethnic, pilgrimage, ecotourism, etc. In general, tourism serves to meet the real socioaesthetic needs of people as an expression of aesthetic consciousness and specific practices that stand on its ground and passes the means of aesthetic education. The structural structure of tourism is multi-layered, in which the aesthetic attitude towards the object, as well as the holistic unity and interdependence of aesthetic activity are first considered. The emotional and mental abilities of a person, his imagination about life, the real thing, created not only on the basis of natural necessity, but also on the basis of the laws of beauty, is a complex system that, in combination with phenomena, includes forms of behavior. On the basis of tourism activities, there is an activity aimed at mastering the world from a practical point of view. In it, the aesthetic consciousness of the subject, the content of his aesthetic relations are materialized. Tourism is a determining factor that determines the direction of aesthetic education as a form of expression of a person's deep interests, aesthetic needs and pleasure relations. At the present time, the form of reflection of the results of the development of the worldview of a person, but also the relationship between society and nature, the embodiment of universal ideas about their importance, is an invariable model.

\section{REFERENCES}

1. B.Kh.Mirzarahimov., "Gnoseological functions of tourism and their philosophical analysis". Journal of philosophy and life. -Tashkent, 2020 №1 (8). - P.123.

2. Khusayn Voiz Koshifiy "Futuvatnomai sultaniy". -Tashkent, Publishing house of the people's architect named after A.Kadiriy, 1994. -P.62.

3. Abu Hamid Gazzoli "Kimyoi saodat" (truth of spirit). "Justice", -Tashkent, 2005. P.196.

4. Usman Hosil. Custom. - Tashkent: "Uzbekistan" NMIU, 2016. -P. 268.

5. Sorokin P. Main trends of our time. Moscow: Scince, 1997. - P.19.

6. Madimarovna, A. I., \& Khoshimovich, M. B. (2020). Factors for the development of tourism culture in the uzbek national value system. ACADEMICIA: An International Multidisciplinary Research Journal,10(4), 575-580. DOI NUMBER: 10.5958/22497137.2020.00116.0

7. Urry J. The Tourist Gaze: Leisure and Travel in Contemporary Societies. London: Sage. 1990. P. 2

8. B.Kh.Mirzarahimov., "Gnoseological functions of tourism and their philosophical analysis". Journal of philosophy and life. -Tashkent, 2020. №1 (8). -P.124.

9. Galizdra A. S., The phenomenon of tourism: socio-philosophical analysis. Autoabstract. -Saratov, 2006. -P.43. 
10. Мирзарахимов, Б. Х. (2019). КУЛЬТУРА

ТУРИЗМА КАК СТРАТЕГИЯ РАЗВИТИЯ

КНИГОВЕДЕНИЯ. In ПЕРСПЕКТИВНЫЕ

ОБЛАСТИ РАЗВИТИЯ НАУКИ И

ТЕХНОЛОГИЙ (рр. 57-58).

11. Mirzarahimov, В. (2019). The factor of good neighborhood and tourism development (Philosophical analysis). Scientific Bulletin of Namangan State University, 1(1), 140-145. 